\title{
The Effect of Lipolytic Enzymes of Bacillus spp. on Quality of Ultra-High- Temperature-Treated Milk
}

\author{
B. JANŠTOVÁ, L. VORLOVÁ, M. DRAČKOVÁ \\ Department of Milk Hygiene and Technology, Faculty of Veterinary Hygiene and Ecology \\ University of Veterinary and Pharmaceutical Sciences Brno
}

Received June 7, 2005

Accepted June 30, 2006

\begin{abstract}
Janštová B., L. Vorlová, M. Dračková: The Effect of Lipolytic Enzymes of Bacillus spp. on Quality of UHT Milk. Acta Vet Brno 2006, 75: 427-435.

Lipolysis was monitored based on determining the concentration of free fatty acids in milk, on the model case of UHT milk contamination with spores of 15 B. licheniformis, B. subtilis and $B$. cereus strains isolated from farm environment and raw milk. Lipolysis was not recorded at storage temperature of $4{ }^{\circ} \mathrm{C}$, whereas significant changes in levels of free fatty acids were shown at storage temperature of $24^{\circ} \mathrm{C}$. After 3 weeks of storage the initial content of $41.97 \mathrm{mmol} \cdot \mathrm{kg}^{-1}$ of fat rose to as much as $1,617.22 \mathrm{mmol} \cdot \mathrm{kg}^{-1}$ of fat. The extent of the change depended mainly on the Bacillus spp. species and the storage period and, to a certain degree, also on the initial number of microorganisms. Significant lipolytic activity was detected in association with $B$. licheniformis and $B$. cereus species. It was found that spores of resistant $B$. licheniformis strains may survive $100{ }^{\circ} \mathrm{C} / 10 \mathrm{~min}$ and $135^{\circ} \mathrm{C} / 5 \mathrm{~s}$ heating and show lipolytic activity.
\end{abstract}

Lipolysis, spores, Bacillus spp., free fatty acids, milk

Bacillus spp. microorganisms represent important contaminants of raw milk from the point of view of both hygiene and technology, and in some cases, human health.

Bacillus spp. spores are commonly present in stables, causing mainly secondary milk contamination during milking. A number of representatives of the Bacillus family are present in milk as psychrotrophic microflora. The species of the Bacillus family most frequently isolated from raw milk are B. licheniformis and B. cereus (Crielly et al. 1994). Páčová et al. (1996) report that the species with the widest distribution is B. licheniformis. The distribution of other species is lower (Lukášová et al. 2001; Vyletělová et al. 2001). Spores of thermostable bacteria may pollute a product even during the technological process, and they may be present in UHT milk, too, as reported e.g. by B ahout (2000), who detected the spores at concentrations of up to $2.6 \times 10^{2} \cdot \mathrm{ml}^{-1}$ in $18.3 \%$ of tested samples.

Bacillus spp. microorganisms are an extremely burdensome part of raw milk microflora, as removing their spores is very difficult due to their thermoresistance. The spores may be partly damaged by pasteurization, but mostly cannot survive sterilization and the UHT process. One important characteristic of Bacillus spp. is the ability of the vegetative cells to produce thermostable extracellular enzymes after proliferation (Meer et al. 1991; Ipsen et al. 2000). The proteolytic and lipolytic activity of these enzymes bears on nutritional and sensory properties of milk products even when no live bacteria are present (B oor et al. 1998). Brown (2000) refers to Bacillus spp. as microorganisms causing significant economic loss.

Some Bacillus spp. species, especially B. cereus, show a high degree of lipolytic and proteolytic activity (Janštová et al. 2004). The enzyme activity is demonstrated in a number of milk and milk-product defects, such as those described by Silveira et al. (1999). Lipolytic enzymes produced by Bacillus spp. microorganisms cause fat hydrolysis

Address for correspondence:

MVDr. Bohumíra Janštová, Ph.D.

Department of Milk Hygiene and Processing

University of Veterinary and Pharmaceutical Sciences

1/3 Palackého St., 61242 Brno, Czech Republic
Phone: +420541562712

Fax: +420 541562711

E-mail: janstovab@vfu.cz

http://www.vfu.cz/acta-vet/actavet.htm 
and production of free fatty acids after germination of spores in milk and milk products. Microbial enzymes are strictly specific and much more active than native lipases (Murray et al. 2001). Johnston and Bruce (1982), who studied lipolytic properties of Bacillus spp., detected fat lipolysis in $52 \%$ of strains and a $77 \%$ prevalence of lecithinase-positive strains.

Since lipases are largely produced by microorganisms in the late lag stage and the early stationary growth stage, there is no direct proportional correlation between the number of microorganisms and the enzyme concentration. Defects are detected when the concentration of microorganisms reaches $5 \times 10^{5}-10^{7} \mathrm{CFU} \cdot \mathrm{ml}^{-1}$ (Vyletělová et al. 2000; Marth and Steele 1998).

Unlike milk lipases, microbial lipases are thermoresistant and remain active despite heating including UHT milk treatment, being able to cause the development of rancid taste and flavour, contributing thus to product degradation. Lipase activity thus presents an obstacle to successful implementation of UHT products where lipases are contained in the raw material, and their activity in the UHT product is preserved.

It is low-carbon fatty acids $\left(\mathrm{C}_{4}-\mathrm{C}_{12}\right)$, especially the butyric acid, that contribute to the development of sensory defects the most. Fatty acids $\mathrm{C}_{4}-\mathrm{C}_{8}$ are to blame for the rancid flavour while the foul, bitter and soapy flavour is due to $\mathrm{C}_{10}-\mathrm{C}_{12}$ fatty acids ( $\mathrm{Ch}$ am pagne et al. 1994).

Lipase activity is enhanced by physical phenomena applied in milk processing such as homogenisation, sudden temperature change, intensive stirring or milk turbulence in the pipes, as they may damage the lipoprotein membrane of fat globules, making the fat vulnerable to lipase activity.

\section{Materials and Methods}

The experiments were conducted on collection strains of the Department of Milk Hygiene and Processing of the University of Veterinary and Pharmaceutical Sciences Brno. A total of 15 Bacillus spp. strains isolated from farm environment and raw milk were used. Each experiment involved 5 B. licheniformis, 5 B. subtilis and 5 B. cereus strains. All the isolated strains were identified by Lukášová et al. (2001). Durable UHT milk distributed on the market was used as the medium for Bacillus spp. spore contamination. The UHT milk originated from the same batch.

Milk was inoculated with Bacillus spp. spore suspensions, without using thermic inactivation, in such an amount as to reach spore concentrations of $10^{2}, 10^{1},<10^{1}$ in $1 \mathrm{ml}$ of milk. Besides that, Bacillus spp. spore suspensions heated to $100{ }^{\circ} \mathrm{C}$ in water bath (exposure time $10 \mathrm{~min}$ ) and to $135^{\circ} \mathrm{C}$ in glycerol bath (exposure time 5 s) were used.

Thermoinactivation of spore suspension $(5 \mathrm{ml})$ was performed after heating to $70{ }^{\circ} \mathrm{C}$. The complete inactivation of $B$. subtilis and B. cereus spores was performed after heating, at $100{ }^{\circ} \mathrm{C}$ for $10 \mathrm{~min}$ and $135^{\circ} \mathrm{C}$ for $5 \mathrm{~s}$. The initial concentration of $B$. licheniformis thermoresistant strain was reduced by 1 logarithmic order.

Milk samples were stored in closed sterile glass sample bottles at $24{ }^{\circ} \mathrm{C}$ in a thermostat and at $4{ }^{\circ} \mathrm{C}$ in a refrigerator.

The proof and quantification of lipolysis due to Bacillus spp. microorganisms was based on the extraction/titration method for determining substance content of free fatty acids (FFA) in accordance with CSN 570533 "Determination of Substance Content of Free Fatty Acids" (1997). The amount of substance for FFA was expressed in $\mathrm{mmol} \cdot \mathrm{kg}^{-1}$ of milk fat. The analysis was performed at 1 -week intervals for 3 weeks. All samples were analyzed in triplicate.

To be able to compare the dynamism of growth of the microorganisms and change the values of observed indicators, we performed a microbiological analysis of milk samples, namely determination of the total number of spore-forming microorganisms (ČSN ISO 6887, 1994). Cultivation was performed on Plate Count Agar (HiMedia, India). Sensory evaluation (colour, coagulum, and odour) was performed, too, when the samples were taken for analysis.

The STAT Plus Statistical and Graphic System (Matoušková et al. 1992) was used to assess the significance of variances of individual indicators at levels $p<0.01$ and $p<0.05$. The data processing was based on dispersion analysis and Scheffe's contrasts the Turkey's test of variance significance. To obtain correct results, the data were subjected to the Box-Cox transformation prior to variance analysis so as to ensure that they meet the condition of basic distribution normality. Before the analysis proper, homogeneity of variances of the tested samples had to be verified. The Bartlett's test was used for this purpose. 


\section{Results and Discussion}

Microorganisms of the Bacillus family are important producers of lipolytic enzymes. Thermoresistant bacterial lipases may represent a serious obstacle to UHT processing of milk products containing fat.

No increase in FFA content due to any of the considered Bacillus spp. species compared with the initial FFA levels occurred during sample storage at $4{ }^{\circ} \mathrm{C}$; the detected levels were consistent with control samples (the results are not mentioned). None of the considered strains proliferated at $4{ }^{\circ} \mathrm{C}$. Our results achieved by FFA content determination in samples stored at this temperature are in line with the conclusions of Burdova (2002), who stressed the importance of storage temperature based on her finding that milk storage temperature of $4{ }^{\circ} \mathrm{C}$ was not high enough to ensure production of an amount of lipolytic and proteolytic enzymes comparable to that produced in samples stored at $10^{\circ} \mathrm{C}$ for $2-3$ days despite the storage period being three times longer.

An increase in FFA caused by lipolytic enzyme activity was recorded only in association with sample storage at $24^{\circ} \mathrm{C}$ and correlated with the increase in the number of microorganisms. Some change was detected already when levels $10^{4}-10^{5} \mathrm{CFU} \cdot \mathrm{ml}^{-1}$ were achieved; CFU peaked in the $3^{\text {rd }}$ week of storage and was identical for all Bacillus spp. thermally non-inactivated strains, namely $10^{8} \cdot \mathrm{ml}^{-1}$ of milk. A lower number of CFU was found when we used non-inactivated B. licheniformis spores. B. subtilis and B. cereus were completely inactivated. No germination or growth was observed. The dynamics of changes of $B$. licheniformis number depending on time storage is demonstrated in Fig. 1. No increase of FFT content was found in control samples during the experiment.

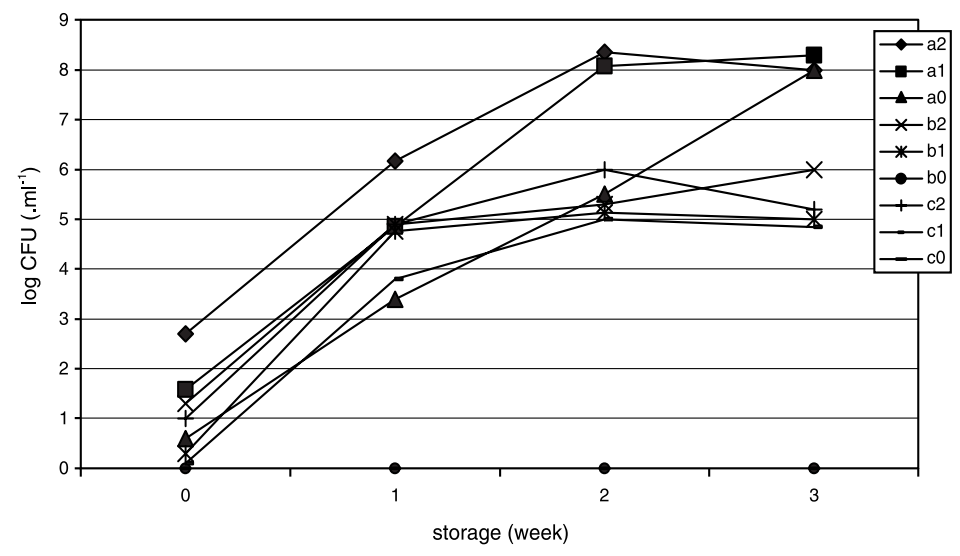

Fig. 1. Dynamics of changes of CFU number in milk containing B. licheniformis spores stored at $24{ }^{\circ} \mathrm{C}$ depending on inactivation method (a - no inactivation, $\mathrm{b}$ - inactivation by heating to $100^{\circ} \mathrm{C} / 10 \mathrm{~min}, \mathrm{c}$ - inactivation by heating to $\left.135^{\circ} \mathrm{C} / 5 \mathrm{~s}\right)$ and initial spore concentration $\left(2=10^{2}\right.$ in $1 \mathrm{ml}, 1=10^{1}$ in $1 \mathrm{ml}, 0=<10^{1}$ in $\left.1 \mathrm{ml}\right)$.

Significant lipolysis was detected in samples with higher initial content of inoculated, thermally non-inactivated spores in milk; small-scale lipolysis was detected in samples containing few individual spores. The average initial FFA content in the milk used for the experiments was $41.97 \mathrm{mmol} \cdot \mathrm{kg}^{-1}$ of milk fat.

As shown in Table 1, the use of the highest concentration of thermally non-inactivated and a 3-week storage period led to an increase of FFA content in milk in relevant $B$. licheniformis strains depending on the initial concentration. The initial number of spores being $10^{2} \cdot \mathrm{ml}^{-1}$, the average content was $330.53 \pm 80.98 ; 940.74 \pm 482.77$; and $1,129.61 \pm 387.42 \mathrm{mmol} \cdot \mathrm{kg}^{-1}$ of 
Table 1. Average FFA content levels ( $\mathrm{mmol} \cdot \mathrm{kg}^{-1}$ of milk fat) in milk containing non-inactivated B.licheniformis, B. subtilis, B. cereus spores. Dependence on storage period (week) at $24^{\circ} \mathrm{C}$

\begin{tabular}{|c|c|c|c|c|}
\hline \multirow[t]{2}{*}{ Species } & \multirow[t]{2}{*}{ Week } & \multicolumn{3}{|c|}{ Initial No. of spores $/ 1 \mathrm{ml}$ of milk } \\
\hline & & $\begin{array}{c}10^{2} \pm \mathrm{SD} \\
\min \\
\max \end{array}$ & $\begin{array}{c}10^{1} \pm \mathrm{SD} \\
\min \\
\max \end{array}$ & $\begin{array}{c}<10^{1} \pm \mathrm{SD} \\
\min \\
\max \end{array}$ \\
\hline \multicolumn{5}{|c|}{ Initial FFA content 41.97} \\
\hline \multirow[t]{9}{*}{ B. licheniformis } & \multirow[t]{3}{*}{1} & $330.53 \pm 80.98$ & $255.89 \pm 138.79$ & $212.12 \pm 131.73$ \\
\hline & & 239.68 & 106.29 & 58.81 \\
\hline & & 443.60 & 446.4 & 353.21 \\
\hline & \multirow[t]{3}{*}{2} & $940.74 \pm 482.77$ & $758.80 \pm 389.69$ & $459.22 \pm 294.36$ \\
\hline & & 417.10 & 329.29 & 147.61 \\
\hline & & 1513.40 & 1265.90 & 942.75 \\
\hline & \multirow[t]{3}{*}{3} & $1129.61 \pm 387.42$ & $1104.82 \pm 366.18$ & $787.68 \pm 144.75$ \\
\hline & & 598.40 & 679.29 & 565.20 \\
\hline & & 1665.40 & 1504.40 & 1109.80 \\
\hline \multirow[t]{9}{*}{ B. subtilis } & \multirow[t]{3}{*}{1} & $145.16 \pm 70.26$ & $124.02 \pm 97.89$ & $79.59 \pm 21.77$ \\
\hline & & 54.67 & 42.94 & 42.98 \\
\hline & & 219.44 & 294.55 & 95.50 \\
\hline & \multirow[t]{3}{*}{2} & $467.78 \pm 161.78$ & $227.74 \pm 89.04$ & $203.24 \pm 38.89$ \\
\hline & & 118.32 & 86.99 & 43.25 \\
\hline & & 515.92 & 332.96 & 138.25 \\
\hline & \multirow[t]{3}{*}{3} & $488.61 \pm 67.67$ & $408.59 \pm 53.57$ & $354.22 \pm 18.54$ \\
\hline & & 280.60 & 191.52 & 43.11 \\
\hline & & 536.46 & 617.75 & 582.16 \\
\hline \multirow[t]{9}{*}{ B. cereus } & \multirow[t]{3}{*}{1} & $241.79 \pm 160.48$ & $202.63 \pm 129.53$ & $157.71 \pm 147.84$ \\
\hline & & 62.24 & 67.13 & 64.69 \\
\hline & & 412.35 & 382.80 & 364.72 \\
\hline & \multirow[t]{3}{*}{2} & $771.44 \pm 485.22$ & $838.98 \pm 559.94$ & $701.96 \pm 438.31$ \\
\hline & & 130.59 & 118.60 & 110.41 \\
\hline & & 1240.70 & 1381.00 & 1109.80 \\
\hline & \multirow[t]{3}{*}{3} & $1617.2 \pm 68.17$ & $1261.1 \pm 31.11$ & $895.0 \pm 13.01$ \\
\hline & & 1502.55 & 1068.25 & 885.60 \\
\hline & & 1665.40 & 1425.50 & 904.40 \\
\hline
\end{tabular}

fat, after 1, 2 and 3 weeks, respectively. The maximum level recorded for the individual strains was $1,665.22 \mathrm{mmol} \cdot \mathrm{kg}^{-1}$ of fat. The initial content of $10^{1} \cdot \mathrm{ml}^{-1}$ led to similarly high levels. The initial spore concentration of $<10^{1} \cdot \mathrm{ml}^{-1}$ produced a high determined amount of FFA, too $\left(787.68 \pm 144.75 \mathrm{mmol} \cdot \mathrm{kg}^{-1}\right.$ of fat $)$.

The number of microorganisms in milk being roughly the same, lipolytic activity of $B$. subtilis enzymes was the least significant compared with other considered bacterial strains. At spore concentration of $10^{2}$ per $1 \mathrm{ml}$ of milk, the average FFA levels were $467.78 \pm 161.78$ $\mathrm{mmol} \cdot \mathrm{kg}^{-1}$ of fat and $488.61 \pm 67.67 \mathrm{mmol} \cdot \mathrm{kg}^{-1}$ of fat after 2 and 3 weeks of storage respectively. The initial spore concentration had a significant differentiating effect on FFA milk content: FFA content was significantly lower at spore content $<10^{1}$ per $1 \mathrm{ml}$ of milk and no FFA content increase at all occurred in 2 of the 5 tested strains.

The B. cereus strain was generally characterized by strong lipolytic activity, to which the high FFA levels found even in samples with the lowest initial spore content testify. The values for the individual strains however varied considerably. With the initial number of spores $10^{2}$ per $\mathrm{ml}^{-1}$, the determined levels of FFA were $241.79 \pm 160.48,771.44 \pm 485.22$ 
and $1617.22 \pm 68.17 \mathrm{mmol} \cdot \mathrm{kg}^{-1}$ of fat. The final FFA content levels at lower spore concentrations were $1,261.1 \pm 31.11$ and $895.00 \pm 13.01 \mathrm{mmol} \cdot \mathrm{kg}^{-1}$ of fat.

Significant variances $(p<0.05)$ and highly significant variances $(p<0.01)$ were found between the activities of individual Bacillus spp. species tested. FFA content for $B$. subtilis was lower $(p<0.05)$ compared with B. licheniformis and lower $(p<0.01)$ compared with B. cereus.

When spores inactivated by heating to $100{ }^{\circ} \mathrm{C}$ for $10 \mathrm{~min}$ were used in samples stored at $24^{\circ} \mathrm{C}$, lipolysis was observed only in the B. licheniformis thermoresistant strain. Thermoresistance of Bacillus spp. spores was described by Janštová and Lukášová (2001). At higher initial concentrations of inoculated spores, the survivor spores of the strain germinated and FFA content increased to 206.36, 417.80 and $605.21 \mathrm{mmol} \cdot \mathrm{kg}^{-1}$ of fat (after $1^{\text {st }}, 2^{\text {nd }}$ and $3^{\text {rd }}$ week of storage). The average FFA content levels after 3 weeks of storage were $230.33 \pm 324.47 \mathrm{mmol} \cdot \mathrm{kg}^{-1}$ (initial concentration of spores was $10^{2} \cdot \mathrm{ml}^{-1}$ ) and 144.25 $\pm 6.26 \mathrm{mmol} \cdot \mathrm{kg}^{-1}$ of fat (initial concentration of spores was $10^{1} \cdot \mathrm{ml}^{-1}$ ) (see Table 2a). When spores of other B. licheniformis strains and also B. subtilis and B. cereus spores were heated, they were eradicated and no lipolysis was recorded (see Table $2 b$ ).

Table 2a. Average FFA content levels ( $\mathrm{mmol} \cdot \mathrm{kg}^{-1}$ of milk fat) in milk containing $B$. licheniformis spores inactivated by heating to $100^{\circ} \mathrm{C} / 10 \mathrm{~min}$. Dependence on storage period (week) at $24^{\circ} \mathrm{C}$

\begin{tabular}{|c|c|c|c|c|}
\hline \multirow[b]{2}{*}{ Species } & \multirow[b]{2}{*}{ Week } & \multicolumn{3}{|c|}{ Initial No. of spores $/ 1 \mathrm{ml}$ of milk } \\
\hline & & $\begin{array}{c}10^{2} \pm \mathrm{SD} \\
\min \\
\max \end{array}$ & $\begin{array}{c}10^{1} \pm \mathrm{SD} \\
\min \\
\max \end{array}$ & $\begin{array}{c}<10^{1} \pm \mathrm{SD} \\
\min \\
\max \end{array}$ \\
\hline \multicolumn{5}{|c|}{ Initial FFA content 41.97} \\
\hline \multirow[t]{9}{*}{ B. licheniformis } & \multirow[t]{3}{*}{1} & $97.19 \pm 95.55$ & $84.12 \pm 0.28$ & $42.11 \pm 0.16$ \\
\hline & & 42.05 & 41.59 & 42.00 \\
\hline & & 206.36 & 70.18 & 42.68 \\
\hline & \multirow[t]{3}{*}{2} & $168.06 \pm 216.29$ & $112.11 \pm 0.31$ & $43.02 \pm 0.22$ \\
\hline & & 42.09 & 42.06 & 42.42 \\
\hline & & 417.80 & 72.56 & 45.02 \\
\hline & \multirow[t]{3}{*}{3} & $230.33 \pm 324.47$ & $144.25 \pm 6.26$ & $43.38 \pm 0.08$ \\
\hline & & 44.28 & 42.06 & 42.11 \\
\hline & & 603.25 & 344.72 & 45.02 \\
\hline
\end{tabular}

Table $2 \mathrm{~b}$. Average FFA content levels ( $\mathrm{mmol} \cdot \mathrm{kg}^{-1}$ of milk fat) in milk containing B. subtilis and B. cereus spores inactivated by heating to $100{ }^{\circ} \mathrm{C} / 10 \mathrm{~min}$. Dependence on storage period (week) at $24^{\circ} \mathrm{C}$

\begin{tabular}{|l|c|c|c|c|}
\hline \multirow{2}{*}{ Species } & \multirow{2}{*}{ Week } & \multicolumn{3}{|c|}{ Initial No. of spores/1 ml of milk } \\
\cline { 3 - 5 } & \multicolumn{2}{|c|}{$10^{2} \pm \mathrm{SD}$} & $10^{1} \pm \mathrm{SD}$ & $<10^{1} \pm \mathrm{SD}$ \\
\hline Initial FFA content 41.97 & & $42.85 \pm 1.37$ & $42.52 \pm 0.57$ \\
\hline \multirow{3}{*}{ B. subtilis } & 1 & $42.35 \pm 0.49$ & $42.63 \pm 1.16$ & $42.88 \pm 1.12$ \\
\cline { 2 - 5 } & 2 & $43.11 \pm 1.51$ & $42.54 \pm 1.12$ & $42.96 \pm 2.08$ \\
\cline { 2 - 5 } & 3 & $43.05 \pm 2.04$ & $43.25 \pm 0.71$ & $43.08 \pm 0.35$ \\
\hline \multirow{3}{*}{ B. cereus } & 1 & $42.58 \pm 0.38$ & $42.15 \pm 1.07$ & $42.42 \pm 1.68$ \\
\cline { 2 - 5 } & 2 & $42.62 \pm 0.71$ & $42.32 \pm 0.98$ & $42.60 \pm 1.25$ \\
\cline { 2 - 5 } & 3 & $42.55 \pm 2.11$ & & \\
\hline
\end{tabular}

When inactivated by heating to $135^{\circ} \mathrm{C}$ for $5 \mathrm{~s}$ (see Table $3 \mathrm{a}$ ), a limited amount of the same $B$. licheniformis thermoresistant strain germinated. With the initial spore concentrations $10^{1}$ and $10^{2} \cdot \mathrm{ml}^{-1}$, the spores germinated to reach $10^{5}-10^{6} \mathrm{CFU} \cdot \mathrm{ml}^{-1}$ of milk. Lipolytic activity 
Table 3a. Average FFA content levels ( $\mathrm{mmol} \cdot \mathrm{kg}^{-1}$ of milk fat) in milk containing $B$. licheniformis spores inactivated by heating to $135^{\circ} \mathrm{C} / 5 \mathrm{~s}$. Dependence on storage period (week) at $24^{\circ} \mathrm{C}$

\begin{tabular}{|c|c|c|c|c|}
\hline \multirow[b]{2}{*}{ Species } & \multirow[b]{2}{*}{ Week } & \multicolumn{3}{|c|}{ Initial No. of spores/ $1 \mathrm{ml}$ of milk } \\
\hline & & $\begin{array}{c}10^{2} \pm \mathrm{SD} \\
\min \\
\max \end{array}$ & $\begin{array}{c}10^{1} \pm \mathrm{SD} \\
\min \\
\max \end{array}$ & $\begin{array}{c}<10^{1} \pm \mathrm{SD} \\
\min \\
\max \\
\end{array}$ \\
\hline \multicolumn{5}{|c|}{ Initial FFA content 41.97} \\
\hline \multirow[t]{9}{*}{ B. licheniformis } & 1 & $100.42 \pm 82.26$ & $100.08 \pm 81.89$ & $42.37 \pm 0.16$ \\
\hline & & 42.25 & 42.17 & 42.25 \\
\hline & & 158.58 & 157.98 & 42.48 \\
\hline & 2 & $302.74 \pm 367.82$ & $199.40 \pm 221.49$ & $42.78 \pm 0.31$ \\
\hline & & 42.65 & 42.78 & 42.41 \\
\hline & & 562.83 & 356.02 & 43.15 \\
\hline & 3 & $537.32 \pm 699.01$ & $473.76 \pm 556.01$ & $42.80 \pm 0.30$ \\
\hline & & 43.04 & 43.12 & 42.24 \\
\hline & & 1031.60 & 904.40 & 43.41 \\
\hline
\end{tabular}

was subsequently demonstrated as an increase in average FFA levels was to $537.32 \pm 699.01$ (initial concentration of spores was $10^{2} \mathrm{ml}^{-1}$ ) $473.76 \pm 556.64 \mathrm{mmol} \cdot \mathrm{kg}^{-1}$ (initial concentration of spores was $10^{1} \cdot \mathrm{ml}^{-1}$ ) of fat in the $3^{\text {rd }}$ week of storage. No increase in FFA content was recorded in samples with the lowest initial inactivated spore concentrations. Spores of other $B$. licheniformis strains and B. subtilis and B. cereus spores were completely inactivated; no lipolysis was recorded (see Table 3a, Table 3b).

Table 3b. Average FFA content levels ( $\mathrm{mmol} \cdot \mathrm{kg}^{-1}$ of milk fat) in milk containing B. subtilis, B. cereus spores inactivated by heating to $135^{\circ} \mathrm{C} / 5 \mathrm{~s}$. Dependence on storage period (week) at $24^{\circ} \mathrm{C}$

\begin{tabular}{|l|c|c|c|c|}
\hline \multirow{2}{*}{ Species } & \multirow{2}{*}{ Week } & \multicolumn{3}{|c|}{ Initial No. of spores/1 ml of milk } \\
\cline { 3 - 5 } & \multicolumn{3}{|c|}{$10^{1} \pm \mathrm{SD}$} & $<10^{1} \pm \mathrm{SD}$ \\
\hline \multirow{2}{*}{ Initial FFA content 41.97} & $10^{2} \pm \mathrm{SD}$ & $42.25 \pm 0.08$ & $42.68 \pm 0.59$ \\
\hline \multirow{3}{*}{ B. subtilis } & 1 & $42.85 \pm 0.50$ & $43.91 \pm 2.11$ & $42.68 \pm 0.69$ \\
\cline { 2 - 5 } & 2 & $43.14 \pm 0.86$ & $43.24 \pm 0.25$ & $42.78 \pm 0.83$ \\
\cline { 2 - 5 } & 3 & $43.32 \pm 0.40$ & $42.38 \pm 0.99$ & $42.73 \pm 0.24$ \\
\hline \multirow{3}{*}{ B. cereus } & 1 & $43.08 \pm 0.85$ & $43.03 \pm 0.33$ & $43.07 \pm 0.38$ \\
\cline { 2 - 5 } & 2 & $43.32 \pm 0.08$ & $43.04 \pm 0.05$ & $43.09 \pm 0.03$ \\
\cline { 2 - 5 } & 3 & $43.29 \pm 0.20$ & & \\
\hline
\end{tabular}

The dynamics of FFA content growth depending on thermo-inactivation mode and initial B. licheniformis spore concentration is shown in Fig. 2.

The significance of the variances between FFA levels detected in samples inoculated with thermoresistant $B$. licheniformis strain spores inactivated by heating to $100{ }^{\circ} \mathrm{C}$ for $10 \mathrm{~min}$ and to $135^{\circ} \mathrm{C}$ for $5 \mathrm{~s}$ on the one hand and the other strains of the same species on the other is highly significant $(p<0.01)$. Just as highly significant variances $(p<0.01)$ were found when average FFA content levels in samples with $B$. licheniformis inoculation were compared with those of other tested Bacillus spp. species.

Our experiments have proved that thermo-inactivation of spores, depending on the temperature, causes reduction or cessation of lipase production as a consequence of sublethal or lethal spore damage. However, if the strain is a thermoresistant one or if 


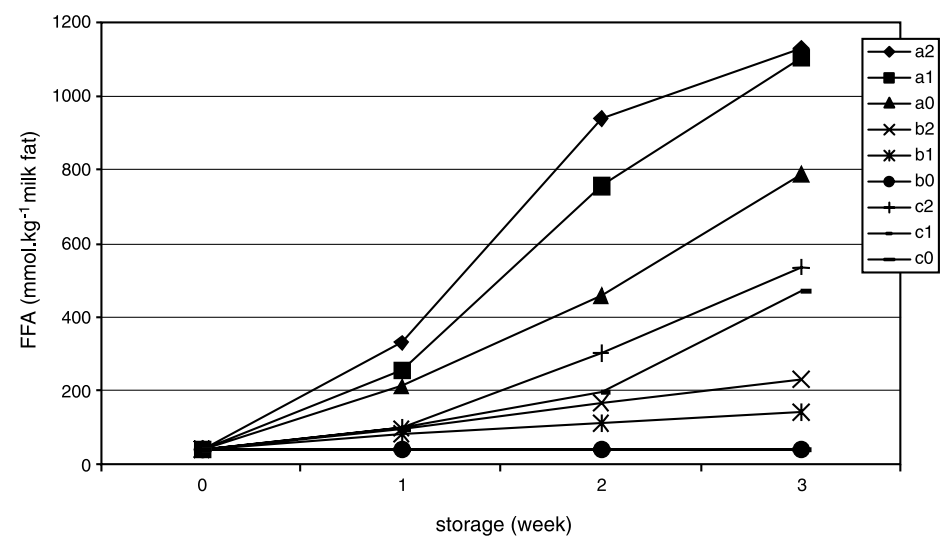

Fig. 2. FFA content in milk containing B. licheniformis spores stored at $24{ }^{\circ} \mathrm{C}$ depending on inactivation method (a - no inactivation, $\mathrm{b}$ - inactivation by heating to $100^{\circ} \mathrm{C} / 10 \mathrm{~min}, \mathrm{c}$ - inactivation by heating to $135^{\circ} \mathrm{C} / 5 \mathrm{~s}$ ) and initial spore concentration $\left(2=10^{2}\right.$ in $1 \mathrm{ml}, 1=10^{1}$ in $1 \mathrm{ml}, 0=<10^{1}$ in $\left.1 \mathrm{ml}\right)$

enzymes are produced before thermic treatment of milk, the spores remain active or partly active even in the finished product. Grieger et al. (1990) report that heating milk above $130{ }^{\circ} \mathrm{C}$ for $5-10 \mathrm{~min}$ leads to reduction of lipases to $10 \%$ and that inactivation of some lipases may require temperatures as high as $150^{\circ} \mathrm{C}$.

Characteristics of microbial lipases and their role in food spoilage was studied e.g. by Stead (1986). In consistence with our findings, Vlachos and Litopoulou-Tzanetaki (1985) report differences as to production of lipolytic enzymes between individual Bacillus spp. species including between strains of the same species. They found no proofs of lipolytic activity of some $B$. licheniformis strains.

Despite the fact that due to differences of focus and use of different determination methods our findings could not be compared with data published by other authors, it is clear that the process of lipolysis can be recorded by the method we used. In contrast to the requirement of CSN 570529 (1993) - requiring that the FFA content in raw milk for dairy technologies and processing determined by the titration/extraction method does not exceed $32 \mathrm{mmol} \cdot \mathrm{kg}^{-1}$ a mild increase in FFA content in UHT milk and a subsequent growth due to lipolysis caused by Bacillus spp. enzymes was observed.

Action of bacterial enzymes produced by microorganisms including some microorganisms from the Bacillus family is the cause of sensory defects of milk and milk products. Enzymes isolated from B. licheniformis, B. coagulans and B. subtilis were studied by Kalogridou-Vassiliadou (1992), reporting an association with milk spoilage. Matta and Punj (1999) speak of a connection between flavour defects and the $48 \%$ prevalence of lipolytic bacillary strains in raw milk samples they detected. Defects originate upon reaching a certain concentration of microorganisms; sensory alterations of milk can be detected at concentrations of $10^{5}-10^{7} \mathrm{CFU} \cdot \mathrm{ml}^{-1}$ (Vyletělová et al. 2000; Marth and Steele 1998; Šilhánková 1999). In contrast to that, the content of psychrotrophic CFU sufficient to initiate lipolysis reported by Silveira et al. (1999) is $2.7 \times 10^{4} \mathrm{CFU} \cdot \mathrm{ml}^{-1}$.

No sensory alterations were recorded in samples stored at $4{ }^{\circ} \mathrm{C}$, despite 3 months of storage, in association with any of the Bacillus species. Deterioration of sensory qualities of milk (bad odour, running) was recorded in samples containing non-inactivated spores stored at $24{ }^{\circ} \mathrm{C}$ in correspondence to the process of lipolysis and proteolysis. No sensory change was detected in thermically inactivated samples, with the exception of milk samples inoculated with B. licheniformis thermoresistant strain spores. In consistence with our 
results, milk defects such as running, gelation, ropiness, colour and flavour defects, fat clotting, and cream bitterness are described by Te Giffel et al. (1996), B assette et al. (1986), Walstra et al. (1999). Cream bitterness is the most widely spread defect caused by B. cereus, the cause being fat destabilization due to phospholipase $\mathrm{C}$, degrading fat globule membranes by enzymatic processes (Al-Kanhal 1985; Meer et al. 1991). Lecithinase, too, causes cream flocculation; the process involves aggregation of fat globules after their envelopes are destructed (Harrigan 1998).

\section{Vliv lipolytických enzymů Bacillus spp. na kvalitu UHT mléka}

Sledování lipolýzy bylo provedeno na základě stanovení látkového obsahu volných mastných kyselin $\mathrm{v}$ mléce a to na modelovém případě kontaminace trvanlivého mléka sporami 15 kmenů $B$. licheniformis, $B$. subtilis a $B$. cereus izolovaných z prostředí farmy a ze syrového mléka. Při skladovací teplotě $4{ }^{\circ} \mathrm{C}$ nebyla lipolýza zaznamenána, zatímco při skladovací teplotě $24^{\circ} \mathrm{C}$ byly zjištovány výrazné změny obsahu volných mastných kyselin. Po 3 týdnech skladování došlo ke zvýšení obsahu volných mastných kyselin z počáteční hodnoty $41.97 \mathrm{mmol} \cdot \mathrm{kg}^{-1}$ tuku na hodnotu až $1617.22 \mathrm{mmol} \cdot \mathrm{kg}^{-1}$ tuku. Rozsah změn závisel především na druhu Bacillus spp. a době skladování a v určité míře také na výchozím počtu mikroorganismů. Výrazná lipolytická aktivita byla zjištěna u druhů $B$. licheniformis a B. cereus. Bylo zjištěno, že teplotní a časový parametr záhřevu na $100{ }^{\circ} \mathrm{C} 10 \mathrm{~min}$ a $135{ }^{\circ} \mathrm{C} 5 \mathrm{~s}$ mohou spory rezistentních kmenů $B$. licheniformis přežít a vykazovat lipolytickou aktivitu.

\section{Acknowledgements}

The study was supported from the grant provided by the Ministry of Education, Youth and Sports of the Czech Republic No. MSM 6215712402.

\section{References}

AL-KANHAL HA, FRANK JF, CHRISTEN GL 1985: Microbial protease and phospholipase C stimulate lipolysis of washed cream. In GRIFFITHS MW 1992: B. cereus in milk and milk products. Bulletin FIL-IDF $275: 37$. J Dairy Sci 68: 3162-6170

BAHOUT AA 2000: Prevalence of Bacillus species in UHT milk. Assiut Vet Med J 42: 47-53

BASSETTE R, FUNG DY, MANTHA VR 1986: Off - flavors in milk. Crit Rev Food Sci Nutr 24: 1-52

BOOR KJ, BROWN DP, MURPHY SC, KOZLOWSKI SM, BANDLER DK 1998: Microbiological and chemical quality of raw milk in New York State. J Dairy Sci 81: 1743-1748

BROWN KL 2000: Control of bacterial spores. Brit Med Bull 56: 158-171

BURDOVÁ O, BARANOVÁ M, LAUKOVÁ A, ROZANSKÁ H, ROLA JG 2002: Hygiene of pasteurised milk depending on psychrotrophic microorganisms. B Vet I Pulawy 46: 325-329

CHAMPAGNE CP, LAING RR, ROY D, MAFU AA, GRIFFITHS MW 1994: Psychrotrophs in dairy products: Their effects and their control. Crit Rev Food Sci Nutr 34:1-30

CRIELLY EM, LOGAN NA, ANDERTON A 1994: Studies on the Bacillus flora of milk and milk products. J Appl Bacteriol 77: 256-263

ČSN ISO 6887 1994: Mikrobiologie. Všeobecné pokyny pro přípravu ředění při mikrobiologickém zkoušení. Český normalizační institut, Praha, 7 p.

ČSN 570529 1993: Syrové kravské mléko pro mlékárenské ošetření a zpracování. Český normalizační institut, Praha, 8 p.

ČSN 570533 1997: Stanovení látkového obsahu volných mastných kyselin. Praha, Český normalizační institut, p. 8.

GRIEGER C, HOLEC J et al. 1990: Hygiena mlieka a mliečnych výrobkov. Bratislava, Príroda, pp. 39-40.

HARRIGAN WF 1998: Laboratory Methods in Food Microbiology. Academic Press. London, pp. 202-245.

IPSEN R, OTTE J, LOMHOLT SB, QVIST KB 2000: Standardized reaction times used to describe the mechanism of enzyme-induced gelation in whey protein systems. J Dairy Res 37: 403-413

JANŠTOVÁ B, LUKÁS̆OVÁ J 2001: Heat resistance of Bacillus spp. spores isolated from cow's milk and farm environment. Acta Vet Brno 70: 179-184

JANŠTOVÁ B, LUKÁŠOVÁ J, DRAČKOVÁ M, VORLOVÁ L 2004: Influence of Bacillus spp. Enzymes on UHT Milk Proteins. Acta Vet Brno 73: 393-400

JOHNSTON DW, BRUCE J 1982: Incidence of thermoduric psychrotrophs in milk produced in the West of Scotland. J Appl Bacteriol 53: 333-337 
KALOGRIDOU-VASSILIADOU D 1992: Biochemical activities of Bacillus species isolated from flat sour evapored milk. J Dairy Sci 75: 2684-2686.

LUKÁŠOVÁ J, VYHNÁLKOVÁ J, PÁČOVÁ Z 2001: Bacillus species in raw milk and in the farm environment. Milchwissenschaft 56: 609-611

MARTH EH, STEELE JL 1998: Applied Dairy Microbiology. Marcel Decker, INC, New York, p. 516.

MATOUŠKOVÁ O, CHALUPA J, CÍGLER M, HRUŠKA K 1992: STAT-Plus uživatelská př́ručka, verse 1.01. Veterinary Research Institute, Brno, CR, p. 168.

MATTA H, PUNJ V 1999: Isolation and identification of lipolytic, psychrotrophic spore forming bacteria from raw milk. Int J Dairy Technol 52: 59-62

MEER RR, BAKER FW, BODYFELT FW, GRIFFITHS MW 1991: Psychrotrophic Bacillus spp. in fluid milk products. A review. J Food Protect 54: 969-979

MURRAY RK, GRANNER DK, MAYES PA, RODWELL VW 2001. Harperova biochemie. H a H Vyšehradská s.r.o.,p. 872.

PÁČOVÁ Z, VYHNÁLKOVÁ J, LUKÁŠOVÁ J, HOLEC J 1996: Identification of aerobic and facultatively anaerobic sporulating bacteria isolated from operations of milk primary production. Ved Med-Czech 41: 19-23

SILVEIRA IA, CARVALHO EP, TEIXEIRA D, BARRIOS BE 1999: Verification of the proteolytic and lipolytic activities of the microbial flora isolated from raw, refrigerated, type B milk. II. Psychrotrophic microorganisms. Rev Latinoam Microbiol 41: 85-89

STEAD D 1986: Microbial lipases: their characteristic, role in food spoilage and industrial uses. J Dairy Res 53: 481-505

ŠILHÁNKOVÁ L. 1999: Mikrobiologie pro potravináře a biotechnology. Victoria publishing a.s., Praha, p. 304.

TE GIFFEL MC, BEUMER RR, BONESTROO MH, ROMBOUTS FM 1996: Incidence and characterization of Bacillus cereus in two dairy processing plants. Neth Milk Dairy J 50: $472-492$

VLACHOS I, LITOPOULOU-TZANETAKI E 1985: Free fatty acid production by some Bacillus strains grown in UHT milk at room temperature. Milchwissenschaft 40: 521

VYLETĚLOVÁ M, HANUŠ O, URBANOVÁ E, KOPUNECZ P 2000: The occurrence and identification of psychrotrophic bacteria with proteolytic and lipolytic activity in bulk milk samples at storage in primary production conditions. Czech J Anim Sci 45: 373-383

VYLETĚLOVÁ M, HANUŠ O, PÁČOVÁ Z, ROUBAL P, KOPUNECZ P 2001: Frequency of Bacillus bacteria in raw cow's milk and relation to other hygiene parameters. Czech J Anim Sci 46: 260-267

WALSTRA P, GEURTS TJ, NOOMEN A, JELLEMA A, BOEKEL MAJS. 1999: Dairy Technology. Principles of Milk Properties and Processes. Marcel Dekker, INC, New York, p. 727. 